\title{
Effect of temperature-humidity-index on milk performances of local born Holstein dairy cows under Saharan climate
}

\author{
Lazoumi Ouarfli*1 and Abdelmadjid Chehma ${ }^{2}$ \\ *corresponding author: lazoumi.ouarfli@univ-ghardaia.dz
}

\begin{abstract}
${ }^{1}$ Département de sciences agronomiques, Faculté des sciences de la nature et de la vie et sciences de la terre, Université de Ghardaia, BP 455, Ghardaia, 47000, Algérie ;

2 Université Kasdi Merbah -Ouargla (Algérie), Laboratoire de Bio ressources sahariennes. Préservation et valorisation 30000 Ouargla, Algérie.
\end{abstract}

\section{ABSTRACT}

The objective is to study the effect of heat stress on milk yield (MY) relative to milking records $(n=18178)$ of native Holsteins $(n=187)$, in the region of Ghardaia, according to periods of HS, using the temperaturehumidity index (THI). With THI $>72$ during 07 months in the study area, which significantly $(\mathrm{P}<0.001)$ decrease the MY $(-15.5 \%$ corresponding to $21.73 \mathrm{~kg})$. Also, calving periods led to a significant drop $(\mathrm{P}<0.001)$ in overall MY (7030.35 kg) of the order of $(-14.6 \%)$, and over the lactation length (353.43 d), which explains $41 \%$ of the variations in MY. In addition, the nonsignificant effect $(\mathrm{P}=0.212)$ of the lactation range on the increase in $\mathrm{MY}$, moreover, the lactation length shows a non-significant $(\mathrm{P}=0.108)$ decrease $(-$ $4.68 \%)$ during heat stress (HS). Furthermore, the significant effect $(\mathrm{P}<0.001)$ of the interaction (Milking frequency $\times \mathrm{THI}$ ) on MY, when THI variates from < 74 to $>84$, with regression of $(-16.82 \%$ and $-08.82 \%)$ of the MF (2X and $3 \mathrm{X})$, respectively. Again, the $\mathrm{NH}$ cow is less sensitive to hyperthermia, so THI explains only $2 \%$ of the variation in MY levels. Thus, $\mathrm{NH}$ in arid regions have the ability to acclimatize to Saharan environmental conditions.

Keywords: Algerian Northern Sahara, THI, native Holsteins, husbandry practices, dairy performance.

\section{INTRODUCTION}

The global geographical distribution of livestock indicates their ability to support extreme climatic conditions, including high temperatures and humidity or drastic droughts (Kadzere et al., 2002). In any case, the Holstein dairy cow is considered the most frequent breed compared to other dairy 
breeds following the creation of dairy industries in tropical and subtropical countries, as this is the most productive breed in the world (Heins et al., 2012). Indeed, this breed has higher caloric expenses resulting from metabolic processes, such as maintenance and milk secretion (Kadzere et al., 2002; Collier et al., 2011), which is the main cause of the high sensitivity of Holstein cows to heat stress (Ravagnolo and Misztal, 2000; Gaughan et al., 2009; Bernabucci et al., 2010; Hammami et al., 2013).

For this purpose, the performances of temperate genotype in tropical conditions are $30-40 \%$ lower than that of the countries of their origin. Environment and genetic ( $\mathrm{G} \times \mathrm{E}$ ) interaction plays an important role in the genetic expression of the overall value (Scholtz et al., 2010). For these reasons, high temperature, relative humidity, wind speed, and solar radiation are conditions that affect the expression of the genetic potential of animals and compromise their well-being (Kadzere et al., 2002; Collier et al., 2017).

Besides, global warming is a major challenge for future dairy cattle production systems. The number of heat stress (HS) days for dairy cows has substantially increased during recent decades (Solymosi et al., 2010). As a result, the temperature-humidity index (THI) is a standard factor for the classifying thermal environments in many animal experiments, and for better managing livestock systems during the summer period (Hahn et al., 2003). In addition, it has been widely used as an indicator of heat stress (Hammami et al., 2013), as it can predict milk losses (Bohmanova et al., 2007; Dikmen and Hansen, 2009), correlated with production and decrease of global performance (Silva et al., 2007; West, 2003) resulting in many economic losses for dairy producers, particularly in tropical countries (Patel et al., 2017).

In lactating Holstein cattle, the comfortable temperature is between the range of 4-24oC (Hahn and Mader, 1997), nonetheless, the upper critical temperature for them is between 25 and 26oC (West, 2003). Furthermore, according to Mader et al., (2006), these critical temperatures vary depending on several factors, including the degree of acclimatization, production level, stage of lactation, and environmental factors within the animal housing.

In effect, quantifying direct environmental effects on milk production is difficult (Fuquay, 1981), because milk production is also strongly affected by other non-environmental factors such as nutrition, individual genetic predispositions of animals, calving season, milking frequency, mammary gland diseases, and livestock management (Heins et al., 2012; MohdNor et al., 2014; Sawa et al., 2015).

To this end, a whole new intensive system has created through specialized dairy cattle farms, in the region of Ghardaia (Algerian Northern Sahara), which is experiencing a real dynamic being characterized by chronic heat stress (Ouarfli and Chehma, 2018), where intense solar radiation and rising ambient temperature extends over a prolonged period, which can reach up to 7 months 
(from April to October). Similar conditions were reported by Mellado et al., (2014) in Mexico.

The aim of this study is to determine the combined effect of environmental conditions and husbandry practices on the daily milk production of native Holstein in the Northern Sahara, according to different physiological stages and parities, and according to periods of heat stress.

\section{MATERIALS AND METHODS}

\section{Animal material and management}

The current research performed on daily milk tests records (18178), during 12 years (2005-2016) on 187 local-born purebred Holstein dairy cows, with parity order from 1st to 8th, located at Ghardaia region, Algerian northern Sahara $\left(32^{\circ} 41^{\prime} 06.7\right.$ "N and $4^{\circ} 44^{\prime} 10.8$ "E). The cows are conducted in an intensive system, in 4 free-stall barns $(6000 \mathrm{~m} 2)$, where the shaded area is $600 \mathrm{~m} 2$ (i.e. $15 \mathrm{~m} 2 / \mathrm{cow}$ ), with metal roofs. Whereas, variation in shaded areas has a direct effect on the behavior and physiology of dairy cows (Schütz et al., 2014).

The cows are artificially inseminated using local semen from National Centre for Artificial Insemination and Genetic Improvement (CNIAG. Algiers). They milked 2X/day (5:00-17:00) to 3X/day (5:00-13:00-21:00), and each milking recorded for each cow in Excel sheet.

\section{Feed and feeding}

Dairy cows receive alfalfa hay and corn silage as a basic ration, supplemented with mixed concentrate feeds (grain maize, soybean meal, wheat bran and Vitamin and mineral premix), as shown in table 1.

Table 1. Daily composition of diets

\begin{tabular}{|c|c|c|c|c|c|c|}
\hline \multirow[t]{2}{*}{ Diet } & \multirow[t]{2}{*}{$\%$ DM } & \multirow{2}{*}{$\begin{array}{c}\text { DMI of } \\
\text { diet } \\
\text { (kg) }\end{array}$} & \multicolumn{4}{|c|}{ Nutrient intake/cow/day } \\
\hline & & & UFL $^{1}$ & $\mathrm{PDI}^{2}$ (g) & $\mathrm{Ca}(\mathrm{g})$ & $\mathbf{P}(\mathrm{g})$ \\
\hline Alfafa hay & 18.14 & 4.3 & 2.92 & 395.6 & 61.92 & 9.46 \\
\hline Corn silage & 42.19 & 10 & 8.5 & 650 & 20 & 18 \\
\hline Wheat bran & 5.91 & 1.4 & 1.29 & 121.8 & 2.24 & 15.68 \\
\hline Soybean meal & 10.54 & 2.5 & 3.02 & 652.5 & 9.75 & 17.75 \\
\hline Maize grain & 23.22 & 5.5 & 6.71 & 407 & 12.65 & 9.9 \\
\hline Total & 100 & 23.7 & 22.44 & 2226.9 & 106.56 & 9.46 \\
\hline
\end{tabular}

Rapport PDI/UFL: 99.23g/UFL, Energy density of diet: $0.95 \mathrm{UFL} / \mathrm{kg}$, Ration fibrosity $\left(\mathrm{ADF}^{3}\right)$ : 24.17\%, Hay/Concentrate ratio: 60/40\%, Dry matter (\%) of ration: 53.31\%, UEL $4: 16.17$.

1: Forage unit for milk production, per kg, ${ }^{2}$ : Digestible proteins in the intestine, in g/kg, ${ }^{3}$ : Acid Detergent Fibre, in \%, 4: Encumbrance unit for lactating females 
Milk production depends both on the udder's ability to synthesize on the one hand and on the availability of nutrients on the other. Therefore, milk synthesis is strongly conditioned by the availability nutrients, linked to the amount ingested and the composition of the ration (Faverdin et al., 2007).

\section{Weather variables}

We used archival meteorological variables (ambient air temperature and relative humidity) 12-years (2005-2016) data from the meteorological station of the region, were used to calculate the temperature humidity index (THI) (Mader et al., (2006) :

$\mathrm{THI}=\left(0.8 \times \mathrm{AT}^{\circ}\right)+\left[(\% \mathrm{RH} / 100) \times\left(\mathrm{AT}^{\circ}-14.4\right)\right]+46.4$.

Where AT is the air temperature in ${ }^{\circ} \mathrm{C}$ and $\mathrm{RH}$ is the relative humidity.

The values of THI: divided into 4 ranges, according to Hahn et al. (2009) classification. The intensity of heat stress, was evaluated as follows: normal, moderate, severe and very severe (emergency) stress, which corresponds to the following values: THI $\leq 74,75-78,79-83$ and $\mathrm{THI} \geq 84$, respectively.

\section{Statistical analysis and variables studied}

In order to facilitate the statistical treatment of the data obtained in the calculations, these data were divided into categories (classes). The data obtained undergoes a descriptive statistical analysis. In addition, the "Comparison of Means" test used to compare the differences in means observed for a quantitative or qualitative variable, as was the "Levens" test on the equality of error differences. In addition, the "Spearman" correlation calculated to find the degree of linkage between the different variables studied. The analysis of variance (One-way ANOVA) of the dependent factor, with a difference of $\mathrm{P}<0.05$ was considered statistically significant. Moreover, the analysis of the regression between the values of daily milk production and THI and those of days in lactation by using "GraphPad Prism 8" software.

\section{RESULTS AND DISCUSSION}

Figure 1.a illustrates the different means of daily milk production $(22.88 \pm 8.11,22.17 \pm 7.83,21.03 \pm 7.70$ and $19.33 \pm 6.31 \mathrm{~kg})$ according to THI classes ( $<74,[75-78]$, [79-83], and $>84$ ), respectively.

Consequently, the increase in THI values led to a significant decrease $(P<$ 0.001 ) in milk yield (kg), with an average regression rate of $-15.51 \%$. Under these conditions, there is a moderate decrease in the average quantity of milk produced per unit of THI in the order of $-0.29 \mathrm{~kg} / \mathrm{THI}$. These results are comparable to those found by Collier et al., (2009), in Arizona, where the daily milk yield decreased by approximately $(-0.27 \mathrm{~kg} / \mathrm{THI})$ during summer heat stress. Nevertheless, Ravagnolo and Misztal, (2000) reported a decrease in milk production of $0.2 \mathrm{~kg} / \mathrm{THI}$, and Brügemann et al., (2012) in Germany 
(Lower Saxony) reported decreases in milk yield of $0.08 \mathrm{~kg}$ per unit of THI in the intensive system, and $0.17 \mathrm{~kg}$ for grazing systems.

In addition, a remarkable decrease $(-40 \%)$ with the lactation stage progress (fig1.b), in the same way, exist a significant correlation between milk production levels and lactation stages $(\mathrm{r}=-0.48 ; P<0.01)$. Thus, the stage of lactation affects the quantity of milk losses resulting from heat stress (Tao et al., 2018). Moreover, in early-lactation, dairy cows exposed to heat stress or thermoneutral conditions experienced similar decreases in milk yield (Lamp et al., 2015), demonstrating that the cows in early-lactation lost milk only due to the effect of reduced dry matter intake (Tao et al., 2018). Besides, dairy cows in mid-lactation are most sensitive to heat compared to those in early or late lactation (Basirico et al., 2009; Bernabucci et al., 2010).
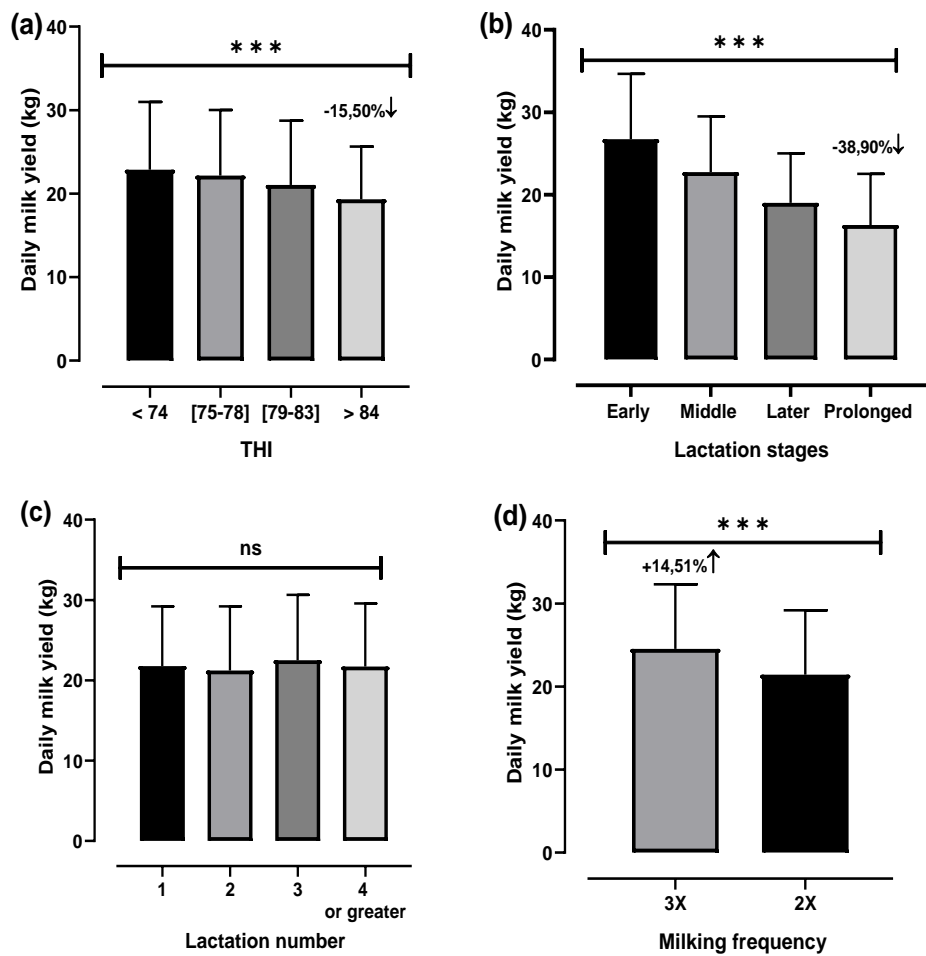

Figure 1. Effect of daily THI (a), lactation stage (b), lactation number (c) and milking frequency (d) on the daily milk yield of local born Holstein dairy cows.

Many studies have established that milk production increases with a parity increasing and has maximized in fourth or fifth lactation (Ray et al., 1992; Cilek, 2009). Nevertheless, in our case, we found that the lactation number had not a significant effect on daily milk yield of cows (fig 1.c). However, the number of lactations also influences milk production under high 
temperature conditions (Amani et al., 2007). Furthermore, when primiparous cows approach their first lactation, they are in a different metabolic state than multiparous cows, as they require nutrients for their own continuous growth, mammary development and milk synthesis (Wathes et al., 2007).

Figure 1.d shows the different average daily milk production levels $(\mathrm{kg})$ of the dairy cows studied, which are of the order of $21.43 \pm 7.75$ and $24.54 \pm 7.75$, as a function of milking frequency (02 times/day and 03 times/day), respectively. These values show that the increase in milking frequency from $(2 \mathrm{X})$ to $(3 \mathrm{X})$ led to a significant increase $(\mathrm{P}<0.001)$ in production $(\mathrm{kg})$, of the order of $+16.4 \%$. To this end, McNamara et al., (2008) reported that milk production increased by up to $14 \%$ by increasing the set milking frequencies from 2 to 3 times per day. In addition, VanRaden et al., (1999) and Stelwagen, (2001), reported that increasing milking frequency from (2X) to (3X), increases milk yield by about $12-14 \%$, regardless of the stage of lactation.
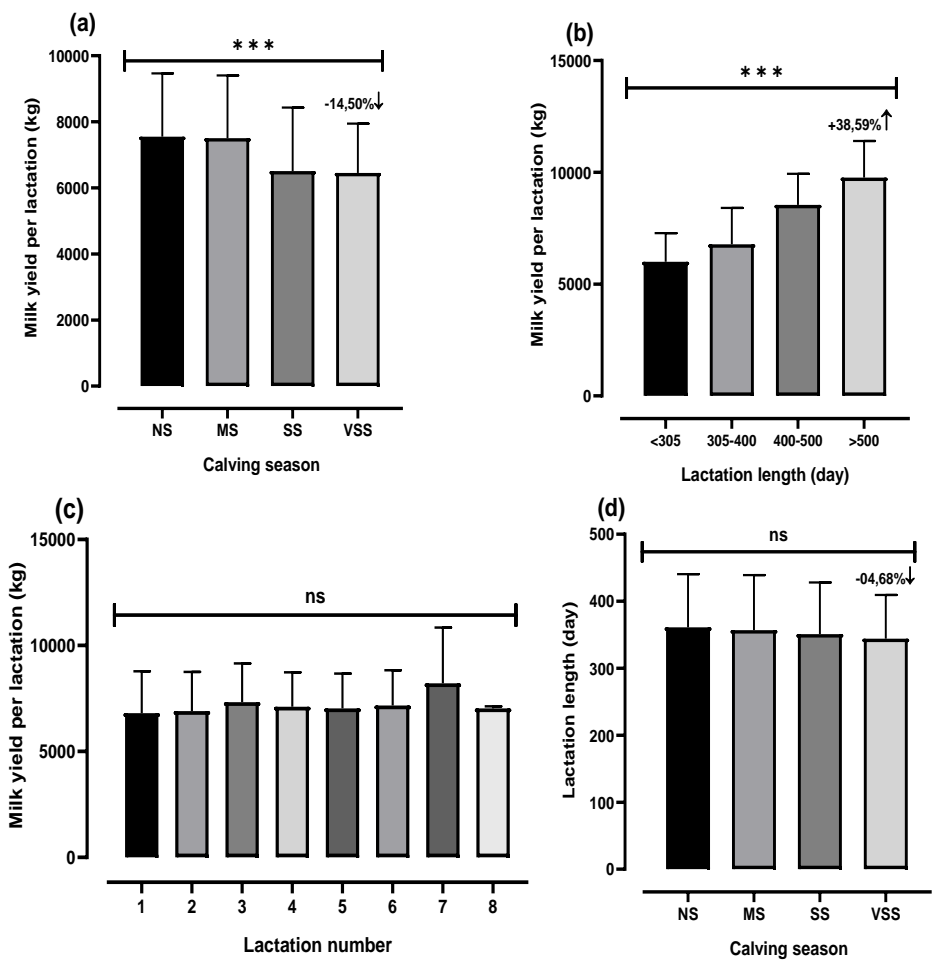

Figure 2. Effect of calving season (a), lactation length (b), lactation number (c) on the daily milk yield per lactation and effect of calving season on the lactation length (d) of local born Holstein dairy cows.

Several studies reflect a great variability in the exteriorization of the genetic potential of the Holstein cow under different environmental 
conditions. For example (Albarrán-Portillo and Pollott, 2011) in temperate zones, (Wondifraw et al., 2013) in tropical and subtropical regions and in the Mediterranean conditions of North Africa by (Bouallegue et al., 2013).

Seasonal variation in calving periods led to a significant decrease $(\mathrm{P}<$ 0.001 ) in the milk yield of dairy cows, in the order of 1258.98 $\mathrm{kg} / \mathrm{cow} / \mathrm{lactation}$, i.e. $-14.60 \%$. In comparison, St-Pierre et al. (2003) estimated milk losses from $436 \mathrm{~kg}$ to $1233 \mathrm{~kg} / \mathrm{cow} /$ year in the South-eastern States (USA). Similarly, the subtropical environment of Louisiana experienced a loss of milk production of $2072 \mathrm{~kg} / \mathrm{cow} /$ year (St-Pierre et al., 2003). In fact, several herds in Florida (U.S.) plan for fall and winter calving (De Vries and Risco, 2005), with the goal of minimizing milk loss, resulting in late-lactation cows producing less milk during the summer months (Ferreira and De Vries, 2015).

Low milk yields were generally associated with short lactation durations or daily production (Hossein-Zadeh, 2013). Indeed, Figure 2.b demonstrates the different mean levels of overall milk yield $(\mathrm{kg})$ of $5996.71 \pm 1284.36$, $6778.87 \pm 1628.65,8541.12 \pm 1389.46$ and $9766.16 \pm 1638.28$, as a function of the classes of their lactation length in days $(<305$, [305-400], [400-500], and $>500$ ), respectively. In this case, longer lactations would have higher yields throughout the lactation (Albarrán-Portillo and Pollott, 2011). Dematawewa et al, (2007) reported that milk yield was higher for longer lactations than standard lactations (305d). With a positive correlation ( $\mathrm{r}=0.64 ; \mathrm{P}<0.01)$ the length of lactation (LL) and global milk yield, of which the (LL) explains $41 \%$ of the variations in milk yield.

Figure 2.c illustrates the different mean levels of overall milk yield (kg), whose means in $\mathrm{kg}$ are 6809.62 $\pm 1968.10,6905.57 \pm 1850.48$, 7328.66 $\pm 1825.42, \quad 7105.86 \pm 1626.24,7057.28 \pm 1651.21,7170.38 \pm 1655.81$, $8213.44 \pm 2637.72$ and $7032.00 \pm 97.06$, according to their lactation ranges $\left(1^{\text {st }}, 2^{\text {nd }}, 3^{\text {rd }}, 4^{\text {th }}, 5^{\text {th }}, 6^{\text {th }}, 7^{\text {th }}\right.$ and $\left.8^{\text {th }}\right)$, respectively. Essentially, all studies have shown that milk yield increases with the number of lactations and has maximized in the fourth or fifth lactation. Nevertheless, according to our results, we notice a significant progression as soon as the sixth lactation. This is the result of the increasing development and size of the udder (Davis and Hughson, 1988) with a consequent increase in the number of secretory cells (Sorensen et al., 2006). Whereas, other reasons for the increase in milk production with increased parity are the differences in tissue mobilization control between primiparous and multiparous cows (Wathes et al., 2007), in addition to the low daily feed intake in primiparous cows compared to multiparous cows (Dado and Allen, 1994).

Lactation length in high producing cows has increased over the last decade (Van Raden 2005, Steri et al. 2010). Currently, in many countries, cows are in lactation beyond 305 days (Vargas et al., 2000). To this end, the lactation length is significantly reduced $(\mathrm{P}<0.001)$, during warm seasons, by 
around $-6.17 \%$ (fig 2.d). Indeed, Okeyo and Mosi, (2001) in semi-arid conditions in Kenya, Bajwaet et al. (2004) and Gajbhaiye et al. (2004) found that the effect of the calving season was very significant $(P<0.01)$ for the duration of lactation. Similarly, Talbi and El Madidi, (2018) reported that the calving season had a very significant effect $(\mathrm{P}<0.001)$ on lactation duration in the Tunisian semi-arid context.

It can view (figure 3.a) that the regression between daily milk production of native Holstein cows and THI values is $\left(\mathrm{n}=18178, \mathrm{P}<0.0001, \mathrm{r}=-0.133, \mathrm{R}^{2}=\right.$ 0.018 ) and the regression equation is (DMY $=29.50-0.106 \mathrm{THI})$. This negative regression obtained under the significant effect of the rise in the values of the temperature-humidity index, whose THI factor explains the $1.8 \%$ decrease in milk production.

(a)

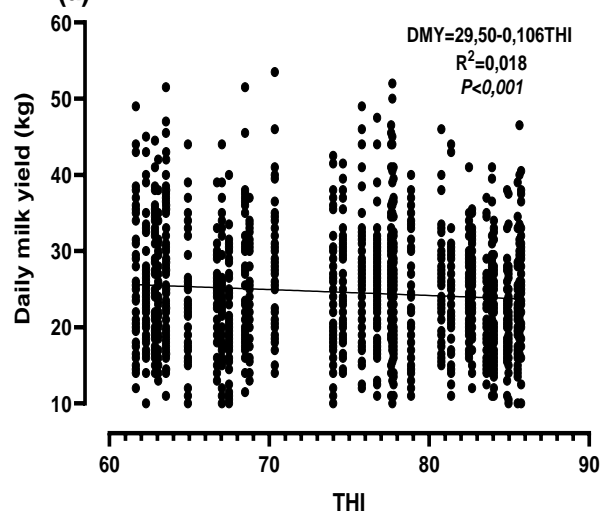

(b)

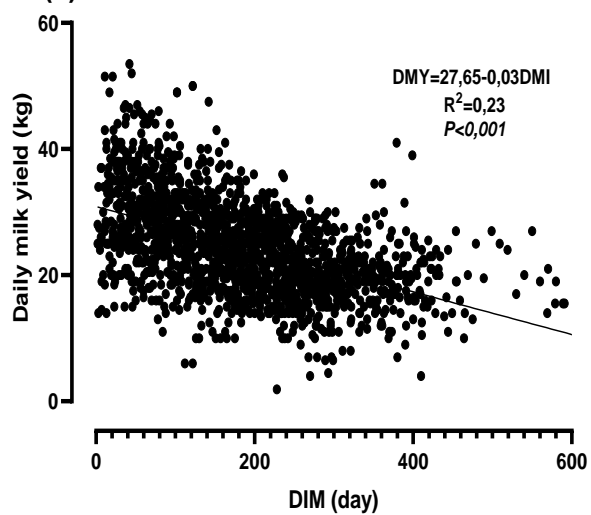

Figure 3. Linear regression of daily milk yield (kg) Holstein dairy cows with THI (a) and days in milk (b).

In this regard, figure 3.b mounts that there is a significant correlation between milk production levels and lactation stages $(r=-0.48 ; \mathrm{P}<0.01)$. Relating to the negative correlation between the stage of lactation (DIM) and the quantity of milk produced, which considered as a factor amplifying the heat stress severity. Moreover, high producing dairy cows, at the beginning of lactation, enter a physiological state during which they are unable to consume enough nutrients to satisfy their maintenance and milk production needs (Drackley, 1999), especially since maintenance needs increase from 7 to $25 \%$ under the effect of heat stress (NRC, 2001) and could even exceed 30\% (Fox and Tylutki, 1998). 


\section{CONCLUSION}

In Saharan regions, the milking performance of native Holsteins, were negatively affected especially in summer periods when THI is above 80 (severe heat stress). Moreover, this deterioration was also linked to other extrinsic factors (calving period, birth period and milking frequency) and intrinsic factors (physiological stage of lactation, parity) and their interactions. Not forgetting that the milk production of Holsteins born in the Saharan regions is certainly quantitatively acceptable compared to imported Holsteins in the same conditions. Still, the native Holstein cow is less sensitive to hyperthermia, whose temperature-humidity index (THI) explains less than $2 \%$ of the variations in the quantity of milk produced. Therefore, Holstein dairy cows born locally in arid regions have the adaptability to the Saharan environmental conditions, especially with adoption of an adequate feeding system, while covering the production and maintenance needs emerging with the rise in temperature of the external environment, without losing the possibility of selecting thermo-resistant individuals.

\section{REFERENCES}

Albarrán-Portillo, B., and Pollott. G., 2011. Environmental factors affecting lactation curve parameters in the United Kingdom's commercial dairy herds. Arch Med Vet., 43, (2), 145- 153.

Amani, Z., Gader, A., Khair, M., Lutfi A., Peters, K., 2007. Milk yield and reproductive performance of Friesian cows under Sudan tropical conditions. Arch Tierz., 50,155-64.

Bajwa, I.R., Khan, M.S., Khan, M.A., Gondal, K.Z., 2004. Environmental Factors Affecting Milk Yield and Lactation Length in Sahiwal Cattle. Pakistan vet.Journal., 24, (1), 23-27.

Basirico, L., Bernabucci, U., Morera, P., Lacetera, N., Nardone, A., 2009. Gene expression and protein secretion of apolipoprotein B100 (ApoB100) in transition dairy cows under hot or thermoneutral environments. Ital. J. Anim. Sci., 8, (2), 592-594.

Bernabucci, U., Lacetera, N., Baumgard, L.H., Rhoads, R.P., Ronchi, B., Nardone, A., 2010. Metabolic and hormonal acclimation to heat stress in domesticated ruminants. Animal, 4, 1167-1183.

Bohmanova, J., Misztal, I., Cole, J.B., 2007. Temperature-humidity indices as indicators of milk production losses due to heat stress. J. Dairy Sci., 90, 1947-1956.

Bouallegue, M., Haddad, B., Aschi, M., Hamouda, M.B., 2013. Effect of environmental factors on lactation curves of milk production traits in Holstein-Friesian cows reared under North African conditions. Lives. Res. Rural. Develop., 25, (5). 
Brügemann, K.E., Gernand, U., König von, B., König, S., 2012. Defining and evaluating heat stress thresholds in different dairy cow production systems. Arc Tierzucht., 55, (1), 13-24.

Cilek, S., 2009. Milk yield traits of Holstein cows raised at Polatli state farm in Turkey. J Anim Vet Adv, 8, 6-10.

Collier, R.J., Zimbelman, R.B., Rhoads, R.P., Rhoads, M.L., Baumgard, L.H., 2009. A Re-evaluation of the Impact of Temperature Humidity Index (THI) and Black Globe Humidity Index (BGHI) on Milk Production in High Producing Dairy Cows. Proceedings of 24th Western Dairy Management Conference (S Virginia) pp, 113-125.

Collier, R., Zimbelman, R., Rhoads, R., Rhoads, M., Baumgard, L., 2011. A reevaluation of the impact of temperature humidity index (THI) and black globe humidity index (BGHI) on milk production in high producing dairy cows. Pages 113-125 in Proc. Western Dairy Management Conf. Reno, NV. USA.

Collier, R.J., Xiao, Y., Bauman, D.E., 2017. Regulation of Factors Affecting Milk Yield. In: Watson, R.R. - Collier J.R. - Preedy, V.: Nutrients in Dairy and Their Implications for Health and Disease. Academic Press, 2017, p. 315. ISBN: 9780128097632.

Dado, R.G., Allen, M.S., 1994. Variation in and relationships among feeding, chewing, and drinking variables for lactating dairy cows. J. Dairy Sci., $77,132-144$.

Davis, S.R., Hughson, G.A., 1988. Measurement of functional udder capacity in lactating Jersey cows. Aust. J. Agric. Res., 39,1163-1168.

De Vries, A., Risco, C.A., 2005. Trends and seasonality of reproductive performance in Florida and Georgia dairy herds from 1976 to 2002. Journal of Dairy Science, 88, (9),3155-3165.

Dematawewa C.M.B., Pearson, R.E., VanRaden, P.M., 2007. Modeling Extended Lactations of Holsteins. J Dairy Sci , 90, 3924-3936.

Dikmen, S., Hansen, P., 2009. Is the temperature-humidity index the best indicator of heat stress in lactating dairy cows in a subtropical environment? Journal of dairy science, 92, (1), 109-116.

Drackley, J.K., 1999. Biology of dairy cows during the transition period: the final frontier? J DairySci., 82, 2259-2273.

Faverdin, P., Delagarde, R., Delaby, R., Meschy, F., 2007. Alimentation des bovins, ovins et caprins: besoins des animaux, valeurs des aliments. Edition Quae. Paris. 307p.

Ferreira, F., De Vries, A., 2015. Effects of season and herd milk volume on somatic cell counts of Florida dairy farms. Journal of dairy science, 98, (6), 4182-4197.

Fox, D.G., Tylutki, T.P., 1998. Accounting for the effects of environment on the nutrient requirements of dairy cattle. J Dairy Sci., 81, 3085-3089. 
Fuquay, J.W., 1981. Heat stress as it affects animal production. J Anim Sci. 52:164-174.

Gajbhaiye, P.U., Brahmashsatri, K.G., Patel, J.S., Panchasara, H.H., 2004. Effect of Service Period on Milk Production of Kankrej Cattle. Ind. Vet. J., 81, 4447.

Gaughan, J.B., Lacetera, N., Valtorta, S.E., Khalifa, H.H., Hahn, L., Mader, T., 2009. Response of domestic animals to climate challenges. In Biometeorology of adaptation to climate variability and change (ed. KL Ebi, I Burton and GR McGregor), pp. 131-170.Springer Science, Heidelberg, Germany.

Hahn, G.L., Mader, T.L., 1997. Heat waves in relation to thermoregulation, feeding behavior and mortality of feedlot cattle In: Proceedings of the $5^{\text {th }}$ International Livestock Environment Symposium Minneapolis, 2931 May. ASAE, St Joseph, Mich,pp 563-567.

Hahn, G.L., Mader, T.L., Eigenberg, R.A., 2003. Perspective on development of thermal indices for animal studies and management. EAAP Tech.Ser., 7, 31-44.

Hammami, H., Bormann, J., M'hamdi, N., Montaldo, H.H., Gengler, N., 2013. Evaluation of heat stress effects on production traits and somatic cell score of Holsteins in a temperate environment. J. DairySci., 96, 18441855.

Heins, B.J., Hansen, L.B., De Vries, A., 2012. Survival, lifetime production, and profitability of Normande $\times$ Holstein, Montbéliarde $\times$ Holstein, and Scandinavian Red $\times$ Holstein crossbreds versus pure Holsteins. J. Dairy Sci., 95, 1011-1021.

Hossein, N.G.Z., 2013. Factors Effecting Lactation Length and Effect of Current Lactation Length on The Subsequent Production and Reproduction in Iranian Holsteins .ArchivTierzucht, 56, 87, 873-881.

Kadzere, C.T., Murphy, M.R., Silanikove, N., Maltz, E., 2002.Heat stress in lactating dairy cows: a review. Livest Prod Sci, 77, 59-91.

Lamp, O., Derno M., Otten, W., Mielenz, M., Nürnberg, G., Kuhla, B., 2015. Metabolic heat stress adaption in transition cows: Differences in macronutrient oxidation between late-gestating and early-lactating German Holstein dairy cows. PloS one, 10,(5), e0125264.

Mader, T.L., Davis, M.S., Brown-Brandl, T., 2006. Environmental factors influencing heat stress in feedlot cattle. J AnimSci, 84, 712-719.

McNamara, S., Murphy, J.J., O'Mara, FP., Rath, M., Mee, J.F., 2008. Effect of milking frequency in early lactation on energy metabolism, milk production and reproductive performance of dairy cows. LivestSci, $117,70-8$.

Mellado, M., Sepulveda, E., Macias-Cruz, U., Avendano, L., Garcia, J.E., Veliz, F.G., Rodriguez, A., 2014. Effects of month of breeding on reproductive efficiency of Holstein cows and heifers inseminated with sex-sorted or 
conventional semen in a hot environment. Trop. Anim. Health Prod., 46, 265-269.

MohdNor, N.M., Steeneveld, W., Hogeveen, H., 2014. The average culling rate of Dutch dairy herds over the years 2007 to 2010 and its association with herd reproduction, performance and health. J. Dairy Res., 81, 1-8.

NRC, 2001. Nutrient Requirements of Dairy Cattle.7th rev. ed. Natl. Acad. Sci., Washington, DC.408 p.

Okeyo, A.M., Mosi, R.O., 2001. Lactation Characteristics of Dutch Friesian Cows Under Semi-Arid Conditions in Kenya : 305 day corrected milk yield and lactation length. The Kenya Vet., 21, 37-42.

Ouarfli, L., Chehma, A., 2018. Effects of thermal stress on milk production of the European breeds Holstein and Montbéliarde in a saharian zone. Lives Res Rural Develop, 30, (11), http://www.lrrd.org/lrrd30/12/ouarf30211.html.

Patel, B., Kumar, N., Jain, V., Ajithakumar, H.M., Kumar, S., Raheja, N., Lathwal, S.S., Datt, C., Singh, S.V., 2017. Zinc Supplementation Improves Reproductive Performance Of Karan-Fries Cattle. I. J. Ani. Repro., 38, (1), 20-22.

Ravagnolo, 0., Misztal, I., 2000. Genetic component of heat stress in dairy cattle, parameter estimation. J Dairy Sci., 83, 2126-2130.

Ray, D.E., Halbach, T.J., Armstrong, D.V., 1992. Season and lactation number effects on milk production and reproduction of dairy cattle in Arizona. J. Dairy Sci., 75, 2976-2983.

Sawa, A., Krężel-Czopek, S., Bogucki, M., 2015. Dry period length as related to milk yield and SCC during the first month of subsequent lactation. Ann. Anim. Sci., 15, 155-163.

Scholtz, M., Furstenburg, D., Maiwashe, A., Makgahlela, M., Theron, H., Van der Westhuizen, J., 2010. Environmental-genotype responses in livestock to global warming: A Southern African perspective. SAJAS., 40, (5), 408-413.

Silva, R.G.D., Morais, D., Guilhermino, M.M., 2007. Evaluation of thermal stress indexes for dairy cows in tropical regions. RevistaBrasileira de Zootecnia, 36, (4), 1192-1198.

Solymosi, N., C. Torma, A. Kern, A. Maróti-Agóts, Z. Barcza, L. Könyves, 0. Berke, and J. Reiczigel. 2010. Changing climate in Hungary and trends in the annual number of heat stress days. Int. J. Biometeorol. 54:423431.

Sorensen, M.T., Norgaard, J.V., Theil, P.K., Vestergaard, M., Sejrsen. K., 2006. Cell turnover and activity in mammary tissue during lactation and the dry period in dairy cows. J. Dairy Sci., 89, 4632-4639.

Stelwagen, K., 2001. Effect of Milking Frequency on Mammary Functioning and Shape of the Lactation Curve. Journal of Dairy Science, (84(E.Suppl.)),E204-E211. 
St-Pierre, N., Cobanov, B., Schnitkey, G., 2003. Economic losses from heat stress by US livestock industries. Journal of dairy science, 86, E52-E77.

Talbi, A., El Madidi, S., 2018. The effect of some environmental factors on milk yield of the Holstein cows raised in a semi-arid climate. International Journal of Agriculture and Environmental Research, 04, 03, 637- 652.

Tao, S., Orellana, R., Weng, X., Marins, T., Dahl, G., Bernard, J., 2018. Symposium review: The influences of heat stress on bovine mammary gland function. Journal of dairy science, 101, (6), 5642-5654. doi: 10.3168/jds.2017-13727. Epub 2018 Jan 10.

VanRaden, P.M., Wiggans, G.R., Van Tassell, C.P., 1999. Changes in USDA-DHIA genetic evaluations. Res. Rep. No. CH13 (2-99). U.S. Dept. of Agric. Anim. Improv. Programs:p. 1-4.

Wathes, D.C., Cheng, Z., Bourne, N., Taylor, V.J., Coffey, M.P., Brotherstone, S., 2007. Differences between primiparous and multiparous dairy cows in the inter-relationships between metabolic traits, milk yield and body condition score in the periparturient period. Domest. Anim. Endocrinol., 33, 203-225.

West, J., 2003. Effects of heat-stress on production in dairy cattle. Journal of dairy science, 86, (6), 2131-2144.

Wondifraw, Z., Thombre, B., Bainwad, D., 2013. Effect of non-genetic factors on milk production of Holstein Friesian $\times$ Deoni crossbred cows. Int. J. Livest. Prod., 4, (7), 106-112. 